\title{
Transformasi Transportasi Tradisional (Offline) ke Transportasi Online Sebagai Solusi Bagi Pengguna di Kota Pontianak
}

\author{
Bustami*, Rio Laksamana \\ Fakultas Ekonomi dan Bisnis, Universitas Tanjungpura, Indonesia
}

\begin{abstract}
This study aims to analyze the transforming offline transportation to Online Transportation, seen from the perception of users in the city of Pontianak. This study describes the perceptions of users of transportation services in the city of Pontianak with the Participatory Action Research (PAR) approach. This research concludes that online transportation is the right solution for the community (users) in the city of Pontianak. The community as a user is of the opinion that online transportation which is present in the midst of the bustle of the community with all its advantages (advantages), is the right solution to replace the use of traditional / offline modes of transportation which are felt to be diminished. The advantages of online transportation such as lower prices, easy to use, flexible, time efficient, various services, fast response and good service. In other words, the existence of online transportation has an important role in meeting the daily needs of users of transportation services for the people in Pontianak.
\end{abstract}

JEL : D10; D12

Keywords : transformation, offline transportation, online transportation, user needs

\section{PENDAHULUAN}

Transportasi online merupakan salah satu inovasi layanan terbaru dalam m-commerce (Silalahi, Handayani, \& Munajat, 2017), sehingga penelitian ini memiliki fokus pada pemanfaatan jasa transportasi online. Berdasarkan pada catatan lembaga riset pasar e-Marketer, bahwa populasi netter tanah air di tahun 2014 mencapai 83,7 juta orang (KOMINFO, 2014). Angka ini berlaku untuk setiap orang yang mengakses internet setidaknya satu kali setiap bulan. Kondisi ini mendudukan negara Indonesia pada peringkat ke-6 terbesar di dunia dalam hal menggunakan internet. e-Market memperkirakan netter Indonesia akan mencapai 112 juta orang, mengalahkan negara Jepang yang di peringkat kelima (KOMINFO, 2014). Perkembangan teknologi internet mengubah gaya hidup masyarakat Indonesia menjadi berbasis teknologi. Hadirnya teknologi internet memudahkan pekerjaan masyarakat Indonesia dalam banyak hal, tak terkecuali mobilitas perjalanan. Meningkatnya akses internet melalui smartphone di kalangan masyarakat Indonesia mengundang hadirnya transportasi online di Indonesia.

\footnotetext{
*Email : bustami_ptk@yahoo.com

Received : 02-11-2018, Accepted : 22-03-2019, Published : 19-12-2019

P-ISSN : 2087-9954, E-ISSN : 2550-0066. DOI : http://dx.doi.org/10.26418/jebik.v8i3.29404
} 
Seiring berkembangnya jaman pada tahun 2010 transportasi berbasis aplikasi online menjadi pendatang baru sebagai layanan yang memudahkan masyarakat Indonesia dalam melakukan mobilitas perjalanan. Di Kota Pontianak sendiri transportasi online mulai ramai peminatnya pada tahun 2017. Yang dipelopori anak bangsa Nadiem Makarim, dengan nama perusahaan transportasi online "Go-Jek". Tidak hanya "Go-Jek", perusahaan transportasi online lainnya juga menyediakan jasa yang sama antara lain yang ada di Kota Pontianak yaitu UBER dan GRAB. Meskipun transportasi online penyebarannya tidak terdapat di semua kota di Indonesia, namun umumnya transportasi online menjadi alternatif utama sebagai jasa transportasi yang dibutuhkan konsumen saat ini. Hasil penelitian Yunus, (2017) menunjukkan bahwa terjadi perubahan perilaku sosial dan ekonomi yang positif pada konsumen Go-Jek seperti menjadi lebih konsumtif dengan layanan yang disediakan Go-Jek.

Faktanya penggunaan jasa transportasi online setiap tahun mengalami peningkatan yang cukup signifikan. Fakta tersebut membuat transportasi tradisional semakin terpinggirkan. Hasil penelitian Priyambodo \& WR, (2013) berkenaan transportasi tradisional memaparkan bahwa angkutan ojek sepeda motor, cenderung tidak berjadwal serta tidak memiliki rute yang pasti. Priyambodo \& WR, (2013) juga menguraikan jarak tempuh operasional ojek sepeda motor tidak terbatas dan bervariasi dengan rute-rute yang tidak terlayani oleh angkutan umum, selanjutnya karakteristik pola pergerakan angkutan ojek sepeda motor berada di luar jaringan angkutan umum angkot/angdes/bus kota. Lebih lanjut, Priyambodo \& WR, (2013) juga menguraikan bahwa karakteristik tarif yang dikenakan kepada penumpang sesuai dengan kesepakatan antara pengojek dengan penumpang dengan proses tawar menawar. Hasil penelitian Septiani, Handayani, \& Azzahro, (2017) menemukan bahwa faktor persepsi internal melalui persepsi kemudahan penggunaan, pengaruh eksternal melalui norma subyektif, karakteristik melalui kompatibilitas yang dirasakan oleh beragam layanan mempengaruhi niat perilaku pengguna pada layanan transportasi di Indonesia.

Berdasarkan latar belakang yang telah diuraikan, adapun tujuan dalam penelitian ini untuk mengetahui bagaimana persepsi pengguna adanya transformasi transportasi online terhadap transportasi tradisional serta peranan transportasi online bagi pengguna di Kota Pontianak. Harapannya dengan mengetahui persepsi pengguna adanya transformasi transportasi online terhadap transportasi tradisional serta peranannya di Kota Pontianak tidak hanya berdampak pada akademisi tetapi juga pembuat kebijakan khususnya di Provinsi Kalimantan Barat. Dalam penelitian ini terbagi menjadi bagian pendahuluan menguraikan latar belakang penelitian, tujuan serta harapan penelitian. Berikutnya, kajian literatur membahas berbagai literatur yang berkenaan dengan transportasi khususnya transportasi online kaitannya dari perspektif ekonomi. Selanjutnya, metoda penelitian menguraikan metoda yang digunakan, data penelitian dan analisa data. Lebih lanjut, hasil penelitian dan pembahasan membahas hasil penelitian serta kesesuaian dengan penelitian sebelumnya, serta simpulan yang merupakan bagian terakhir.

\section{KAJIAN LITERATUR}

Transportasi memiliki peranan penting dalam menghubungkan bahan baku dan hasil produksi ke konsumen. "Pengangkutan berperan penting untuk saling menghubungkan daerah sumber bahan baku, daerah produksi, daerah pemasaran dan daerah pemukiman sebagai tempat tinggal konsumen" (Daldjoeni, 2003). Pemilihan transportasi tergantung dan ditentukan dari 
beberapa faktor yang ada antara lain: segi pelayanan, kehandalan, kehandalan dalam bergerak, keperluan, keselamatan dalam perjalanan, fleksibilitas, biaya, tingkat polusi, jarak tempuh, penggunaan bahan bakar dan kecepatan gerak (Andriansyah, 2015). Penelitian Rahul \& Verma, (2013) di India membuktikan bahwa manfaat ekonomi yang di dapat dengan penggunaan kendaraan yang bukan motor, seperti pengurangan kemacetan, pengurangan polusi udara, kecelakaan, biaya pemeliharaan kendaraan, serta penghematan Rupee India yang terjadi pergeseran $1 \%$ untuk pelancong ke India yang lebih memilih kendaraan yang bukan motor.

Terdapat beberapa penelitian yang relevan dengan penelitian ini. Relevan yang dimaksud dalam pengertian dan kesamaan topik yang dibahas namun temuannya berbeda pada masingmasing peneliti. Kesimpulan dari beberapa peneliti sebelumnya adalah sebagai berikut. Pribadiono, (2016), berkesimpulan bahwa kedudukan subjek hukum driver selaku penyedia jasa transportasi dalam transportasi online sumber hukumnya jelas serta model persaingan usaha antara keduanya tidak sepadan, karena tidak didasarkan teori aple to aple. Damayanti, (2017), dengan fokus penelitiannya pada tindakan sosial masyarakat di Kota Surabaya dalam menggunakan sarana transportasi. Paradigma yang digunakannya adalah paradigma definisi sosial dengan pendekatan kualitatif. Hasil yang ditemukan dalam penelitian ini antara lain, pertama, tindakan sosial yang dilakukan oleh pengguna adalah rasional instrumental dan afeksi, kedua, tindakan afeksi juga muncul dari pihak keluarga untuk menyarankan dan menentukan transportasi yang tepat, dan ketiga, transportasi berbasis aplikasi online menyediakan jasa layanan pemesanan makanan, pengantar barang dan belanja yang dapat dimanfaatkan oleh ibuibu rumah tangga ataupun wirausaha rumahan dalam berbelanja maupun pengantaran barang. Hasil penelitian Olievera (2017) menunjukkan responden di Belo Horizonte, Brazil lebih memilih pemesanan makanan, belanja dan pengantaran barang dengan menggunakan aplikasi online dibandingkan transportasi offline.

Amajida, (2016), berargumen bahwa teknologi menyediakan kemungkinan bagi masyarakat sipil yang tidak memiliki kuasa akan manajemen pelayanan publik untuk mengatasi masalah kepastian sebagai upaya mengatasi risiko pada transportasi publik di Jakarta. Studi ini memperlihatkan bahwa aplikasi yang digunakan "ojek online" Go-Jek mampu meminimalisir risiko yang terjadi di Jakarta dalam hal waktu, kemudahan, biaya, dan keamanan. Syafrino, (2017), menganalisis tingkat efisiensi ojek online dalam transportasi umum, dampak keberadaan ojek online terhadap perluasan kesempatan kerja, dan kesejahteraan pengemudi ojek online. Hasil analisis menunjukkan bahwa dibandingkan dengan angkutan kota (angkot), ojek online merupakan alat transportasi yang lebih efisien dalam hal waktu perjalanan, namun sebaliknya tidak untuk biaya transportasi yang lebih mahal dibandingkan angkot. Ngo, (2015), menguji efisiensi ojek online dalam transportasi umum, dampak keberadaan ojek online terhadap perluasan kesempatan kerja, dan kesejahteraan pengemudi ojek online. Hasil penelitian Ngo, (2015) terjadi mobilitas tenaga kerja pengemudi taksi, terdapatnya 3000 lebih pengemudi yang kemudian pindah bekerja untuk mengemudi di salah satu TNC dari 8500 pengemudi taksi konvensional di San Francisco Amerika.

Paronda, Regido, \& Napalang, (2016), menyatakan bahwa, pertama, Uber dan TNC lainnya di Metro Manila menerapkan konsep sharing economy yang membuat TNC di Metro Manila lebih murah dibandingkan dengan taksi tradisional. Kedua, prinsip sharing economy yang dimiliki TNC adalah strategi alternatif untuk kepemilikan mobil pribadi kemudian menjadi alternatif lain dalam menikmati layanan taksi. Ketiga, dampak yang ditimbulkan dari car sharing 
antara lain, mengurangi kepemilikan kendaraan, mengurangi kendaraan wisata, mengurangi emisi, meningkatkan penumpang angkutan umum, mengurangi pengeluaran rumah tangga. Keempat, Uber dan GrabCar di Metro Manila tidak melakukan prinsip ride sharing namun melakukan pelayanan yang sama dengan taksi konvensional yaitu layanan premium yang permintaan perjalanannya telah ditentukan sebelumnya.

Wang, (2015), menganalisis dampak dari berkembangnya transportasi online terhadap angkatan kerja. Hasil dari penelitian Wang, (2015) menunjukan berkembangnya Transportation Network Companies (TNC) di Las Vegas Amerika, telah meningkatkan angkatan kerja yang bekerja dari 7,314 menjadi 9,019 orang. Anwar, (2017), menganalisis keunggulan dan konflik antar moda transportasi online dan konvensional di kota Makassar. Hasil penelitian Anwar, (2017) ditemukan bahwa transportasi online telah menjadi alternatif transportasi bagi masyarakat karena sejumlah alasan: kepraktisan, transparansi, kepercayaan, keamanan, asuransi, fitur, diskon dan tingkat promosi, serta peluang kerja/paruh waktu baru. Keberadaan transportasi online juga telah menyebabkan konflik antara keduanya. Walaupun, transportasi online dianggap mampu memfasilitasi pengemudi dan penumpangnya. Namun, transportasi online dikritik pengemudi transportasi konvensional karena faktanya membuat mereka terpinggirkan. Konflik antara keduanya umumnya didasarkan pada izin operasi, warna pelat kendaraan yang secara signifikan berdampak pada pembayaran pajak, basis perekrutan penumpang, dan tarif transportasi online. Angka tersebut telah menjadi salah satu kelebihan transportasi online serta salah satu sumber konflik antara transportasi konvensional dan online.

Nasution, (2018), menganalisis tinjauan hukum terhadap layanan transaksi dan transportasi berbasis aplikasi online. Hasil penelitian Nasution, (2018) mengemukakan konstruksi hukum yang tercipta dari transaksi dan transportasi online bervariasi tergantung jenis layanan yang diminta. Pengaturan mengenai perlindungan hukum bagi konsumen belum jelas, demikian pula tidak ada pengaturan mengenai pembagian resiko yang sewaktu-waktu dapat terjadi akibat keadaan memaksa atau overmacht. Anindhita, Arisanty, \& Rahmawati, (2016) berkesimpulan bahwa dari adanya ojek online sebagai Inovasi baru memberikan perubahan pada dua tataran yang berbeda yaitu pertama lingkungan masyarakat dengan keputusan untuk menggunakan jasa ojek online ini untuk kebutuhan mobilisasi mereka. Kedua pada tataran bisnis di bidang jasa, adanya fenomena ojek online ternyata memberikan ide bagi bisnis di bidang jasa lainnya untuk mengkolaborasikan bisnisnya dengan teknologi internet.

Puspitasari, Priyatama, \& Astriana, (2018), menyimpulkan, pertama, terdapat hubungan signifikan antara psychological contract dan person organization fit dengan motivasi kerja pada driver Go-Car di Surakarta, kedua, terdapat hubungan signifikan antara psychological contract dengan motivasi kerja pada driver Go-Car di Surakarta, ketiga terdapat hubungan yang signifikan antara person-organization fit dengan motivasi kerja pada driver Go-Car di Surakarta. Hasil analisa Puspitasari, Priyatama, \& Astriana, (2018) juga menunjukkan variabel psychological contract memberikan pengaruh yang lebih besar pada motivasi kerja jika dibandingkan dengan variabel person-organization fit. Sedangkan untuk hambatan yang dihadapi dalam transportasi online menggunakan Go-Jek di Kota Pontianak, adanya penipuan yang dilakukan oleh masingmasing pengemudi transportasi online Go-Jek ke UMKM dan konsumen (Suratman, Laksamana, \& Suradi, 2018). 


\section{METODA PENELITIAN}

Metoda yang digunakan dalam penelitian ini adalah metode deskriptif dengan pendekatan Participatory Action Research (PAR). PAR merupakan penelitian yang melibatkan secara aktif semua pihak-pihak yang relevan dalam mengkaji tindakan yang sedang berlangsung, dalam hal ini pengalaman responden sendiri sebagai persoalan, dalam rangka melakukan perubahan dan perbaikan ke arah yang lebih baik (Afandi, Sucipto, \& Muhid, 2015; Anney, 2014). Data yang digunakan ialah data primer, dengan sampel sebanyak 42 responden pengguna aplikasi transportasi online. Penarikan sampelnya dilakukan dengan teknik purposive sampling. Yang dijadikan responden dalam penelitian ini adalah pengguna rutin aplikasi transportasi online paling sedikit tiga kali dalam sepekan. Jadi pengguna jasa transportasi online yang bersifat insidentil tidak dimasukkan sebagai responden.

Dalam penelitian ini, peneliti bertindak langsung sebagai driver Go-Car yang memiliki aplikasi. Data dikumpulkan melalui wawancara langsung, dalam hal ini pada saat peneliti sebagai driver dari pengguna jasa transportasi online. Selain itu dilakukan juga pengamatan dan observasi. Peneliti juga menggunakan data sekunder seperti berbagai sumber literatur serta dari berbagai situs internet yang mendukung hasil dari data primer.

Analisis data dalam penelitian berdasarkan atas persentase jawaban responden setiap katagori pernyataan. Ada lima pernyataan utama yang dijadikan dasar penilaian terhadap sikap responden sebagai pengguna jasa transportasi online. Pernyataan tersebut kemudian dijabarkan secara rinci pada bagian lampiran. Kelima pernyataan dimaksud adalah, pertama, transportasi online diterima, mudah digunakan, bermanfaat dan fleksibel, kedua, persepsi responden tentang keunggulan transportasi online, ketiga, transportasi online memiliki pelayanan yang memuaskan, keempat, transportasi online menawarkan bonus/diskon dan tarif/harga terjangkau, dan kelima, transportasi online dapat direkomendasikan kemasyarakat dan dapat menjadi pengganti transportasi tradisional.

\section{HASIL PENELITIAN DAN PEMBAHASAN}

Kondisi angkutan umum di Kota Pontianak dewasa ini semakin memprihatinkan. Kondisi ini ditengarai oleh jumlah kendraan roda 2 yang setiap hari terus bertambah banyak. Hal ini terjadi karena semakin mudahnya masyarakat mendapatkan kendaraan, terutama kendaraan bermotor roda 2 dengan cara cicilan pada beberapa perusahaan leasing. Banyaknya masyarakat yang menggunakan kendaraan bermotor, khususnya roda 2, menyebabkan penggunaan angkutan umum seperti oplet dan bis kota mengalami penurunan. Bahkan untuk bis kota, dewasa ini tidak satupun beroperasi di Kota Pontianak.

Kepala Dinas Perhubungan, Komunikasi dan Informatika Kota Pontianak, Utin Sri Lena Candramidi menyebutkan, transportasi umum, khususnya oplet berjumlah 700 unit, namun kini tinggal 46,43\% saja yang masih beroperasi di wilayah kota ini (Pontianak Post, 2016). Berkurangnya jumlah armada transportasi tradisional (offline) tersebut membuat kesulitan tersendiri bagi sebagian masyarakat dalam menjalankan aktivitas, terutama mereka yang tidak memiliki kendaraan sendiri serta memiliki banyak kegiatan. Akan lebih terasa lagi bagi mereka yang datang dari luar kota dan tidak memiliki keluarga di Pontianak. Alternatif lain adalah 
adanya jasa ojek pangkalan, namun harganya cukup memberatkan pengguna layanan jasa tersebut.

Bagi perusahaan penyedia aplikasi untuk transportasi online, kondisi obyektif yang ada di Kota Pontianak dewasa ini, menjadi suatu peluang untuk mengembangkan aplikasi sebagai basis transportasi online. Oleh karenanya Kota Pontianak merupakan salah satu wilayah pengembangan transportasi online yang ada di pusat Ibu Kota Jakarta. Tepatnya pada awal 2017, PT. Gojek Indonesia yang bergerak dibidang transportasi online berekspansi ke Kota Pontianak pada bulan April tahun 2017 sudah beroperasional di kota Pontianak, setelah itu diikuti transportasi online dari perusahaan lainnya seperti GRAB. Kota Pontianak sebagai daerah yang sedang berkembang, sangat membutuhkan transportasi yang mendukung kegiatan aktivitas sehari-hari.

Hasil penelitian ini tentang persepsi responden menunjukkan bahwa pernyataan transportasi online diterima, mudah digunakan, bermanfaat dan fleksibel dalam penggunaan oleh masyarakat, tercatat sebanyak 62 persen responden berpendapat sangat setuju, 37 persen responden berpendapat Setuju dan 1 persen berpendapat netral. Hal ini menunjukan bahwa transportasi online telah diterima dengan baik dan positif oleh masyarakat Kota Pontiana. Penelitian ini sejalan dengan penelitian Damayanti (2017) dan Anwar (2017). Bagi para pengguna, transportasi online tidak perlu terminal/pangkalan sehingga membuat waktu lebih efisien. pernyataan ini didukung oleh 48 persen responden sangat setuju dan 38 persen responden setuju serta 14 persen responden berpendapat netral. Hal ini menunjukan bahwa keunggulan transportasi online telah dirasakan oleh masyarakat sebagai pengguna.

Keunggulan dimaksud antara lain efisiensi waktu, dalam hal ini pengguna tidak perlu berdiri di pinggir jalan untuk menunggu datangnya armada angkutan atau mendatangi pangkalan ojek/ terminal serta sampai ke tujuan lebih cepat. Keunggulan ini dikarenakan transportasi online memiliki jangkauan yang luas dibandingkan dengan transportasi tradisional (offline) karena tidak perlu rute khusus yang ditentukan oleh pemerintah daerah. Selain itu, perjalanan ke tujuan lebih cepat sampai karena jalan-jalan non formal dapat dilalui oleh transportasi online. Kondisi tersebut membuat aktivitas pengguna jasa transportasi online lebih cepat dan produktif.

Pernyataan ini sejalan dengan temuan Amajida, (2016) serta Pribadiono, (2016). Keunggulan yang membuat pengguna lebih produktif tersebut, mengisyaratkan bahwa transportasi online mampu hadir sebagai alat bantu dalam aktivitas pengguna yang tinggi, tidak hanya membawa penumpang saja (go-ride) tetapi juga dapat membantu masyarakat berbelanja (go-shop), mengirimkan paket barang (go-send), promosi usaha UMKM (go-food) dan lain sebagainya.

Dalam penelitian ini, persepsi responden tentang transportasi online memiliki pelayanan yang memuaskan dalam melayani pengguna sebanyak 32 persen mengatakan sangat setuju, 46 persen berpendapat setuju, 21 persen mengatakaan netral, dan 1 persen berpendapat tidak setuju. Ada hal yang menarik dari tabel 4.2.6 yaitu adanya persepsi responden tentang transportasi online yang memiliki kendaraan terawat dan pelayanan yang baik berpendapat tidak setuju. Hal ini disebabkan responden pernah merasa dikecewakan oleh oknum pengemudi transportasi online, yang mana kendaraan yang digunakan pengemudi tidak terawat, kendaraan tidak sesuai dengan data dilayar layanan smartphone pengguna, dan sikap yang acuh atau tidak membantu terhadap pengguna layanan menjadi alasan bagi para pengguna berpendapat tidak setuju. 
Adapun $78 \%$ responden dalam penelitian ini yang mengatakan sangat setuju dan setuju berpendapat bahwa pengguna dapat memiliki pilihan yang banyak dan sesuai dengan kebutuhan. Dalam hal penggunaan jasa layanan go-ride dan go-car misalnya, kesannya seakan-akan pengguna memiliki kendaraan dan sopir pribadi yang selalu berganti-ganti kendaraan. Pelayanan yang baik, dilayani dengan sopan sampai pelayanan yang memuaskan, dapat dirasakan oleh pengguna. Hal ini juga di senada dengan latar belakang penelitian sebelumnya yang telah dilakukan oleh (Amajida, 2016; Damayanti, 2017; Pribadiono, 2016; Syafrino, 2017) tentang banyaknya macam layanan yang ditawarkan oleh transportasi online disbanding dengan transportasi tradisional/offline.

Kepastian tarif/harga yang telah ditentukan oleh perusahaan berdasarkan per kilometer adalah salah satu kelebihan yang tidak dimiliki oleh transportasi tradisional/offline, sehingga pengguna merasa tidak akan dirugikan dan pengguna dapat mengukur kemampuan bayar sebelum melakukan transaksi. Persepsi responden tentang transportasi online menawarkan bonus/diskon dan tarif/harga terjangkau menunjukan bahwa 52 persen mengatakan sangat setuju, 31 persen mengatakan setuju, serta sisanya sebesar $17 \%$ berpendapat netral. Hal ini menunjukan bahwa lebih dari $83 \%$ pengguna merasakan dampak dari strategi perusahaan transportasi online (salah satunya menawarkan bonus/ diskon) dalam persaingan merebut pasar terhadap sesama kompetitor. Sama halnya dengan penelitian yang dilakukan oleh (Ngo, 2015) di negara Amerika dan Paronda et al., (2016) di negara Filipina bahwa ada terjadinya perpindahan pengguna dan pekerja dari transporasi tradisional/konvensional/offline ke transportasi online.

Adapun persepsi responden dalam penelitian ini tentang transportasi online dapat direkomendasikan kepada masyarakat dan dapat menjadi pengganti transportasi tradisional, sebanyak 62 persen responden berpendapat sangat setuju, 35 persen responden berpendapat Setuju, 1 persen responden berpendapat Netral dan 2 persen berpendapat tidak setuju. Data tersebut menunjukkan 97 persen setuju dengan transportasi online direkomendasikan ke masyarakat sebagai pengganti transportasi tradisional/offline yang ada. Hal ini senada dengan penelitian yang dilakukan oleh Ngo, (2015) dan Paronda et al., (2016) yang menyatakan bahwa transportasi online menjadi solusi dan alternatif moda transportasi di jaman teknologi yang mengedepankan kemudahan.

Dalam penelitian ini, terdapat 2 persen responden berpendapat tidak setuju, mengungkapkan alasannya yang perihatin kepada para pekerja transportasi tradisional/offline yang terancam tidak memiliki perkerjaan dikarenakan sepinya penumpang yang telah berpindah ke transportasi online. Ini juga menjadi temuan penelitian yang dilakukan pada kota Las Vegas dan San Fransisco Amerika oleh (Wang dan Ngo, 2015 dan 2015) terhadap berkembangnya trasportasi online berbanding lurus dengan meningkatnya angkatan kerja yang berkerja di bidang ini, dengan meninggalkan transportasi tradisional/offline. Sama halnya dengan peneliti didaerah lain menemukan adanya peningkatan tenaga kerja dibidang transportasi online, pada kota Jakarta yang dilakukan penelitian Syafrino, (2017) dan pada kota Makassar yang dilakukan penelitian Anwar, (2017). Sedangkan di Kota Semarang, hasil penelitian Rakhmatulloh, Tyas \& Subianto (2018) menemukan bahwa dengan adanya keberadaan bisnis Go-Jek telah menyebabkan adanya penyerapan tenaga kerja kelompok umur 26-30 tahun.

Dikarenakan peranan transportasi online yang telah menjadi kebutuhan masyarakat kota Pontianak, pemerintah daerah harus ikut andil dalam mengatur aturan kebijakan terhadap 
transportasi online, agar tidak adanya keributan seperti demo atau perseteruan yang dilakukan oleh pihak transportasi tradisional/offline seperti di kota-kota lainnya. Selanjutnya, masyarakat sebagai pengguna transportasi online harus dapat memanfaatkan secara maksimal dalam penggunaannya, tidak hanya menjadi moda transportasi, namun dapat dimanfaatkan sebagai peluang usaha baru di bidang lainnya. Transportasi online bermanfaat dan membantu pengusaha UMKM di Pontianak, seperti promosi produk, atau memberikan produk kepada konsumen serta berdampak langsung dirasakan oleh pengusaha hingga 30\% (Suratman et al., 2018).

\section{SIMPULAN}

Berdasarkan hasil analisis dalam tulisan ini, peneliti berkesimpulan bahwa transpormasi transportasi offline ke transportasi online merupakan solusi yang tepat bagi masyarakat sebagai pengguna di kota Pontianak. Masyarakat sebagai pengguna berpendapat bahwa transportasi online dengan segala kelebihan ataupun keunggulan yang ada menjadi solusi untuk mengganti moda trasportasi tradisional/offline yang ada di kota Pontianak. Kelebihan yang dimiliki transportasi online seperti harga lebih murah, mudah digunakan, fleksibel, efisien waktu, layanan beraneka macam, respon yang cepat dan layanan yang baik membuat transportasi online kini memiliki peranan penting dalam menunjang aktivitas kebutuhan sehari-hari, yang tidak dapat dipisahkan dengan masyarakat di kota Pontianak.

\section{DAFTAR PUSTAKA}

Afandi, A., Sucipto, M. H., \& Muhid, A. (2015). Modul Participatory Action Research (PAR) untuk Pengorganisasian Masyarakat (Community Organizing). Surabaya: LPPM UIN Sunan Ampel.

Amajida, F. D. (2016). Kreativitas Digital dalam Masyarakat Risiko Perkotaan: Studi Tentang Ojek Online "Go-Jek" di Jakarta. INFORMASI Kajian Ilmu Komunikasi, 46(1), 115-127. https://doi.org/10.21831/informasi.v46i1.9657

Andriansyah. (2015). Manajemen Transportasi Dalam Kajian dan Teori. Jakarta Pusat: Fakultas Ilmu Sosial dan Ilmu Politik Universitas Prof. Dr. Moestopo Beragama.

Anindhita, W., Arisanty, M., \& Rahmawati, D. (2016). Analisis Penerapan Teknologi Komunikasi Tepat Guna pada Bisnis Transportasi Ojek Online (Studi pada Bisnis Gojek dan Grab Bike dalam Penggunaan Teknologi Komuniasi Tepat Guna untuk Mengembangkan Bisnis Transportasi). Prosiding Seminar Nasional INDOCOMPAC, 2, 712-729.

Anney, V. N. (2014). Ensuring the quality of the findings of qualitative research: looking at trustworthiness criteria. Journal of Emerging Trends in Educational Research and Policy Studies, 5(2), 272-281. https://doi.org/10.3109/08941939.2012.723954

Anwar, A. A. (2017). Online vs Konvensional: Keunggulan dan Konflik Antar Moda Transportasi di Kota Makassar. ETNOSIA : Jurnal Etnografi Indonesia, 2(2), 220-246. https://doi.org/10.31947/etnosia.v2i2.3012

Daldjoeni, N. (2003). Geografi Kota dan Desa. Bandung: Alumni.

Damayanti, S. A. S. (2017). Transportasi Berbasis Aplikasi Online: Go-Jek Sebagai Sarana Transportasi Masyarakat Kota Surabaya. Retrieved from http://journal.unair.ac.id/download-fullpapers-kmnts41437683f2full.pdf 
KOMINFO. (2014). Pengguna Internet Indonesia Nomor Enam Dunia. Retrieved from http://kominfo.go.id

Nasution, D. M. A. (2018). Tinjauan Hukum Terhadap Layanan Transaksi dan Transportasi Berbasis Aplikasi Online. RESAM, 4(1), 17-30. Retrieved from https://media.neliti.com/media/publications/235690-tinjauan-hukum-terhadap-layanantransaks-9152a9a7.pdf

Ngo, V. (2015). Transportation Network Companies and the Ridesourcing Industry: A Review of Impacts and Emerging Regulatory Frameworks for Uber. https://doi.org/10.14288/1.0220795

Paronda, A. G. A., Regido, J. R. F., \& Napalang, M. S. G. (2016). Comparative Analysis of Transportation Network Companies (TNCs) and Conventional Taxi Services in Metro Manila. 23rd Annual Conference of the Transportation Science Society of the Philippines, (August), 1-12.

Pontianak Post. (2016). Angkutan Umum Kian Tak Populer Di Kota Pontianak. Retrieved from http://pontianakpost.co.id

Pribadiono, A. (2016). Transportasi Online Vs Transportasi Tradisional Non-Online Persaingan Tidak Sehat Aspek Pemanfaatan Aplikasi Oleh Penyelenggara Online. Lex Jurnalica, 13(2).

Priyambodo, \& WR, D. J. (2013). Karakteristik Angkutan Ojek Sepeda Motor Di Kabupaten Sidoarjo (Studi Kasus Angkutan Ojek Sepeda Motor di Kecamatan Candi). Jurnal Penelitian Transportasi Darat, 15(3), 151-158.

Puspitasari, I., Priyatama, A. N., \& Astriana, S. (2018). Motivasi Kerja pada Driver Go-Car Ditinjau dari Psychological Contract dan Person-Organization Fit. Jurnal Manajemen Dan Kewirausahaan, 6(2), 181-188. https://doi.org/10.26905/jmdk.v6i2.2357

Rahul, T. M., \& Verma, A. (2013). Economic impact of non-motorized transportation in Indian cities. Research in Transportation Economics, 38, 22-34. https://doi.org/10.1016/j.retrec.2012.05.005

Septiani, R., Handayani, P. W., \& Azzahro, F. (2017). Factors that Affecting Behavioral Intention in Online Transportation Service: Case study of GO-JEK. Procedia Computer Science, 124, 504-512. https://doi.org/10.1016/j.procs.2017.12.183

Silalahi, S. L. B., Handayani, P. W., \& Munajat, Q. (2017). Service Quality Analysis for Online Transportation Services: Case Study of GO-JEK. Procedia Computer Science, 124, 487495. https://doi.org/10.1016/j.procs.2017.12.181

Suratman, E., Laksamana, R., \& Suradi, R. (2018). Perception of Entrepreneurs of Small and Medium Micro Enterprises in Culinary Fields in Pontianak City to Go-Jek Online Transportation. Asian Journal of Social Science Studies, 3(4), 44-50. https://doi.org/10.20849/ajsss.v3i4.519

Syafrino, A. (2017). Efisiensi dan Dampak Ojek Online Terhadap Kesempatan Kerja dan Kesejahteraan. https://doi.org/10.1002/ejsp.2570

Wang, A. (2015). The Economic Impact of Transportation Network Companies on the Taxi Industry. Scripps Senior Theses. Retrieved from http://scholarship.claremont.edu/scripps_theses/703

Yunus, M. (2017). GO-JEK Sebagai Simbol Perubahan Sosial Dan Ekonomi Di Kota Tegal. EQUILIBRIA Jurnal Ilmiah Pendidikan Ekonomi, 2(2), 59-68. https://doi.org/http://dx.doi.org/10.26877/ep.v2i2.2133 


\section{LAMPIRAN}

Tanggapan responden terhadap transformasi transportasi dari offline ke transportasi berbasis aplikasi online

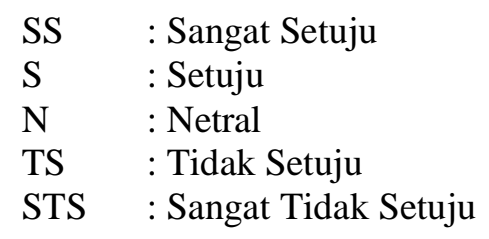

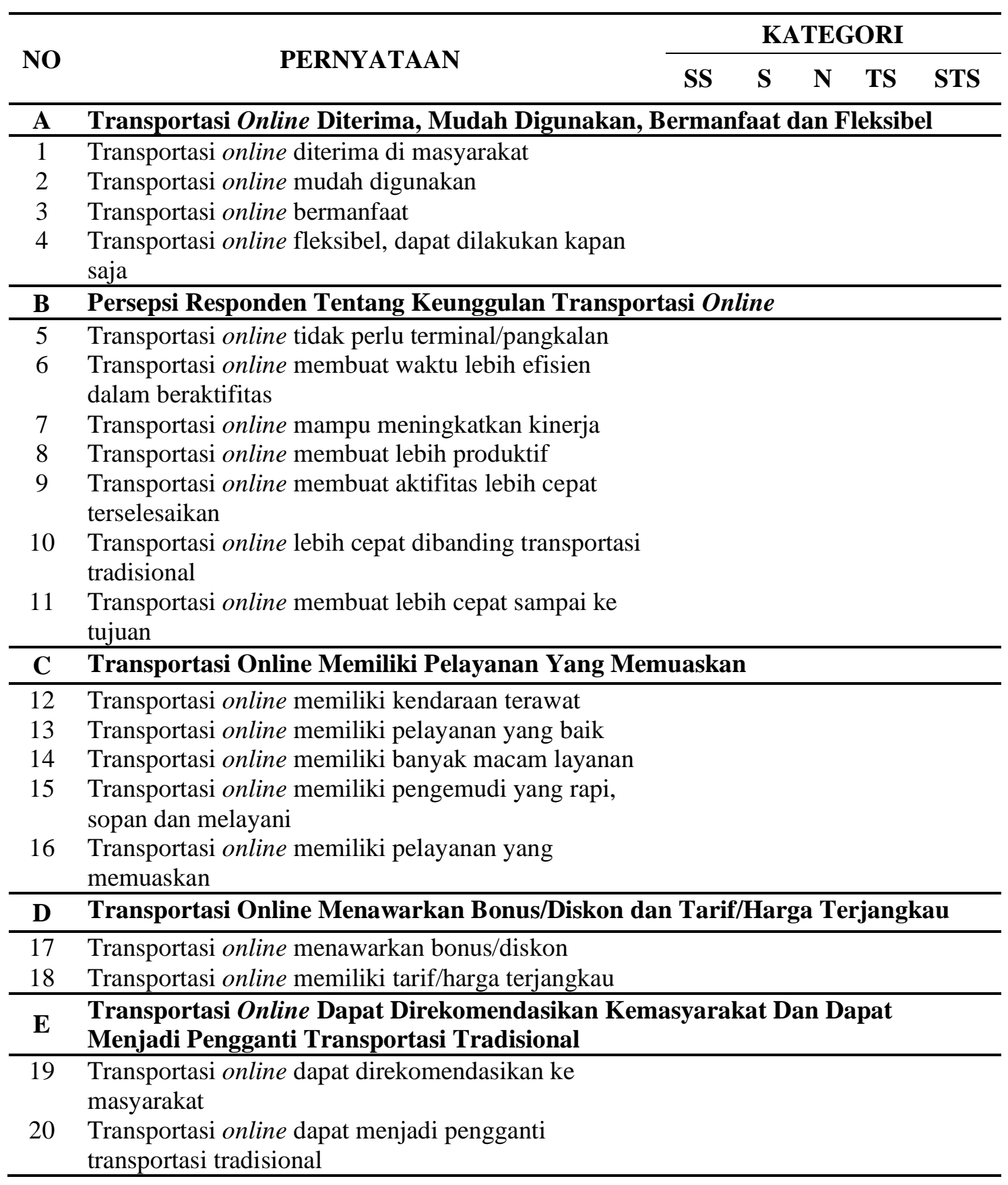

